\title{
Secretion of proteins by Coxiella burnetii
}

\author{
Thomasina Redd $\nmid$ and Herbert A. Thompson
}

Author for correspondence: Herbert A. Thompson. Tel: +1 304293 3951. Fax: +1 3042937823.

Department of Microbiology and Immunology, Health

Sciences Center, West

Virginia University,

PO Box 9177, Morgantown,

WV 26506-9177, USA
Viable Coxiella burnetii organisms were isolated from the culture medium of persistently infected Baby Hamster Kidney (BHK-21) fibroblasts. When these organisms were incubated in host-cell-free medium at low pH, some of the de novo-synthesized protein made by the bacteria was translocated to the exterior of the cell. The exported protein was detectable after 2-7 $\mathrm{h}$ incubation at $37^{\circ} \mathrm{C}$. No evidence was found to suggest that protein accumulation in the medium was due to leakiness caused by cell damage. Both DCCD (dicyclohexylcarbodiimide) and CCCP (carbonyl cyanide $m$-chlorophenylhydrazone) inhibited the process to some extent. Exported protein was represented largely by three polypeptides with molecular masses of 34, 24 and $12 \mathrm{kDa}$. De novo-synthesized proteins corresponding to these molecular masses were not detected in cytoplasmic fractions, but a membrane fraction might possess a similar form. It was concluded that a physiological process of protein translocation occurred in C. burnetii during acid activation in a defined medium. Organisms that were extracted directly from the cytoplasm of infected fibroblasts by a mechanical disruption procedure were also active in de novo protein synthesis; however they exported much less of the protein.

Keywords: Coxiella burnetii, protein secretion, intracellular bacteria

\section{INTRODUCTION}

Coxiella burnetii is an obligate intracellular prokaryotic parasite and the aetiological agent of $Q$ fever in humans. The organism grows within the phagolysosomal compartment in eukaryotic hosts (Burton et al., 1971; Hackstadt \& Williams, 1981a; Akporiaye et al., 1983). Metabolic activity, but not growth, can be detected when the organism is incubated in defined media that contain oxidizable substrates and a sufficient hydrogen ion concentration (Hackstadt \& Williams, 1981a; Zuerner \& Thompson, 1983). This is called acid activation of metabolism. During acid activation in media containing low concentrations of glucose, glutamate and amino acids, $C$. burnetii synthesizes RNA and at least 30 polypeptide species (Zuerner \& Thompson, 1983; Chen et al., 1990).

The functions and activities of proteins on the C. burnetii cell surface are likely to be important for understanding aspects of its intracellular survival and growth (Williams, 1981; Williams \& Waag, 1991). Basic knowledge of the

Abbreviations: CCCP, carbonyl cyanide m-chlorophenylhydrazone; DCCD, dicylohexylcarbodiimide; IBHK cells, persistently infected Baby Hamster Kidney cells.

† Present address: Alderson-Broaddus College, Philippi, WV 26416, USA. synthesis and export of proteins to the outer membrane, or into the organism's exterior growth environment, is therefore of interest. It seemed reasonable to assume that some of the polypeptides synthesized during acid activation of $C$. burnetii in vitro may be transported to membranous and extracellular compartments. If so, study of the synthesis and translocation of proteins in C. burnetii during acid activation in a host-cell-free, defined medium could provide a convenient alternative to the more difficult approach with studies of protein translocation performed in vivo, i.e. during residence in eukaryotic hosts.

The present communication identifies a population of $C$. burnetii that translocates protein during acid activation of metabolism in vitro. Some of the proteins synthesized de novo are found in the membrane fraction. A few polypeptides are exported from the cell by an active process.

\section{METHODS}

Organisms and hosts. Coxiella burnetii, Nine Mile strain, phase I, was originally obtained from Dr David Paretsky, University of Kansas, Lawrence, KS, USA. Baby Hamster Kidney cells (BHK-21) were obtained from the American Type Culture Collection (CCL10). The fibroblasts were grown in Dulbecco's Modified Eagle's Medium (DMEM) which was amended to provide a high glucose concentration $\left(4.5 \mathrm{~g} \mathrm{l}^{-1}\right.$; the use of 
standard Dulbecco's containing 1.0 g glucose $\mathrm{l}^{-1}$ will not produce the results described herein). The DMEM was supplemented with $3.7 \%(\mathrm{w} / \mathrm{v})$ sodium bicarbonate and $10 \%(\mathrm{v} / \mathrm{v})$ newborn calf serum, and fibroblasts were then grown under a $15 \%(\mathrm{v} / \mathrm{v}) \mathrm{CO}_{2}$ atmosphere. C. burnetii phase I organisms were passaged in guinea pigs, and spleen homogenates were used to establish persistent infections in fibroblast cultures as described previously (Zuerner \& Thompson, 1983).

Growth, harvest and preparation of $\mathbf{C}$. burnetii. Six days prior to harvest of organisms, confluent persistently infected fibroblasts (referred to as IBHK cells) were trypsinized, washed, diluted in medium, and then reseeded in new flasks such that a $1: 3$ dilution (1/3 split) of fibroblast density occurred. Seventytwo hours later, the medium on the IBHK monolayers was changed. After another $48 \mathrm{~h}$, the medium was again changed, and two populations of $C$. burnetii were harvested $12-16 \mathrm{~h}$ later. This timing (of the culture feeding and splitting schedule) was important for obtaining high yields of active organisms, as was the maintenance of a $15 \% \mathrm{CO}_{2}$ atmosphere during growth.

Naturally released $C$. burnetii organisms were harvested from spent tissue culture medium by methods described previously (Zuerner \& Thompson, 1983; Chen et al., 1990). The resulting pellets were washed twice in buffer A $\left(22.3 \mathrm{mM} \mathrm{K}_{2} \mathrm{HPO}_{4}\right.$, $136.7 \mathrm{mM} \mathrm{KCl}, \quad 13.4 \mathrm{mM} \mathrm{NaCl}, \quad 89 \mathrm{mM}$ glycine, $10 \mathrm{mM}$ $\mathrm{MgCl}_{2} \cdot 6 \mathrm{H}_{2} \mathrm{O}, 1.0 \mathrm{mM}$ glucose, $1.0 \mathrm{mM}$ glutamate, $250 \mathrm{mM}$ sucrose, $\mathrm{pH} 7 \cdot 0$ ). Organisms prepared in this manner appear to be morphologically and structurally intact (McCaul et al., 1991a).

Mechanically released $C$. burnetii were obtained from the remaining adherent fibroblast population as described by Zuerner \& Thompson (1983). The efficiency of fibroblast lysis was $87-93 \%$, as estimated by the trypan blue exclusion method applied to fibroblast preparations before and after vortex lysis. Unlysed cells showed little or no evidence of intracellular $C$. burnetii when assessed by Gimenez staining.

The numbers of physical particles of $C$. burnetii resulting from these harvest methods were estimated by the Silverman method (Silverman et al., 1979). An $80 \mathrm{~cm}^{2}$ monolayer culture of IBHK fibroblasts $\left(3 \times 10^{7}\right.$ host cells) yielded approximately $1 \times 10^{9}$ organisms in the medium (naturally released C. burnetii), and $34 \times 10^{9}$ organisms from disrupted host cells (mechanically released $C$. burnetii).

Labelling of $\boldsymbol{C}$. burnetii proteins during growth in tissue culture. Medium was removed from IBHK cells $12 \mathrm{~h}$ prior to harvest. Fresh DMEM (13.5 ml, containing all 20 amino acids) plus newborn calf serum $(1.5 \mathrm{ml})$ was supplemented with $0.43 \mathrm{ml} \quad \mathrm{L}-\left[4,5-{ }^{3} \mathrm{H}\right]$ leucine $\left[1.0 \mathrm{mCi} \quad(37 \mathrm{MBq}) \mathrm{ml}^{-1}, \quad 100 \mathrm{Ci}\right.$ $\mathrm{mol}^{-1}$ ], $0.78 \mathrm{ml}$ sterile distilled water and $0.15 \mathrm{ml}$ of a $1 \mathrm{mg} \mathrm{ml} \mathrm{mg}^{-1}$ solution of cycloheximide, and was added to each $75-80 \mathrm{~cm}^{2}$ monolayer of IBHK cells. The IBHK cells were then incubated for $12 \mathrm{~h}$ at $37^{\circ} \mathrm{C}$ in a $15 \% \mathrm{CO}_{2}$ atmosphere. Naturally released and mechanically released $C$. burnetii organisms were then harvested and purified as described above. These organisms, and proteins released from them, were used for protein release studies as indicated in Results.

Radiolabelling of $\boldsymbol{C}$. burnetii proteins during acid activation of metabolism: basic assay. Naturally released or mechanically released $C$. burnetii organisms were suspended (separately) in cold buffer B (49 mM KH $\mathrm{PO}_{4}, 169 \mathrm{mM} \mathrm{KCl}, 16 \mathrm{mM} \mathrm{NaCl}$, $120 \mathrm{mM}$ glycine, $135 \mathrm{mM} \mathrm{KCl}, 13.4 \mathrm{mM} \mathrm{NaCl}, 20 \mathrm{mM} \mathrm{MgCl}$, $250 \mathrm{mM}$ sucrose, $0.1 \mathrm{mM}$ glutamate, $0.1 \mathrm{mM}$ glucose, and the remaining 18 naturally occurring amino acids, each at $0.06 \mathrm{mM}$; final $\mathrm{pH} 4 \cdot 5)$. Either $\mathrm{L}-\left[4,5-{ }^{3} \mathrm{H}\right]$ leucine $[1.67 \mathrm{Ci} \quad(61.8 \mathrm{GBq})$ $\left.\mathrm{mmol}^{-1}\right]$ or $\mathrm{L}-\left[5-{ }^{3} \mathrm{H}\right]$ proline $\left[1.67 \mathrm{Ci}(61.8 \mathrm{GBq}) \mathrm{mmol}^{-1}\right]$ was included in the $1.0 \mathrm{ml}$ incubation mixtures. Alternatively, some experiments utilized $\mathrm{L}-\left[\mathrm{U}-{ }^{14} \mathrm{C}\right]$ leucine $[0.208 \quad(7 \cdot 7 \mathrm{GBq}) \mathrm{Ci}$ $\mathrm{mmol}^{-1}$. Incubations were carried out in sterile capped tubes at $37^{\circ} \mathrm{C}$ under an air atmosphere, with constant shaking, for either 4,7 or $16 \mathrm{~h}$ depending upon the experimental protocol. Timecourse studies were performed by the removal of $50-100 \mu \mathrm{l}$ samples at the designated times. Samples were either (1) applied directly to Whatman no. 3 filter paper discs, dried, and then processed for trichloroacetic acid (TCA)-insoluble radioactivity by the method of Mans \& Novelli (1960) or (2) centrifuged, with cell pellets and supernates assayed separately for TCAprecipitable protein radioactivity as specified below. Counting efficiency for ${ }^{3} \mathrm{H}$ was $23-25 \%$, and for ${ }^{14} \mathrm{C}, 65-70 \%$.

Fractionation and analysis of labelled proteins. Samples $(100 \mu \mathrm{l})$ were removed from incubation mixtures and centrifuged for $7-10 \mathrm{~min}$ (at $6-10^{\circ} \mathrm{C}$ ) with a Fisher model $235 \mathrm{~B}$ microcentrifuge. Supernatant solutions were removed, applied to Whatman no. 3 discs and hot TCA-precipitable radioactivity analysed by liquid scintillation spectrometry (Mans \& Novelli, 1960). Cell pellets containing cell-associated radioactivity were suspended in buffer A. The suspension $(100 \mu \mathrm{l})$ was applied to discs, and TCA-precipitable radioactivity determined by the same inethod.

In some experiments, the $C$. burnetii cell pellets were further fractionated by a $\mathrm{NaOH}$ technique (Russel \& Model, 1982). Cell pellets were suspended in $1 \mathrm{ml} \mathrm{0.1} \mathrm{M} \mathrm{NaOH}$ (made fresh from a $10 \mathrm{M}$ stock). After vigorous mixing, the preparations were placed in an ice bath for $1 \mathrm{~h}$, and were then centrifuged in a microfuge for $15 \mathrm{~min}$. Supernatants were acidified by addition of $0.1 \mathrm{ml} 100 \%$ (w/v) TCA; $1 \mathrm{ml} 5 \%$ (w/v) TCA was added to the pellet fractions. After incubation in an ice bath for $15 \mathrm{~min}$, both fractions were centrifuged for $15 \mathrm{~min}$ and the supernatants discarded. The pellets from each fraction (membrane or cytoplasm) were finally suspended in distilled water, applied to Whatman no. 3 discs, dried, treated with TCA, dehydrated, and radioassayed (Zuerner \& Thompson, 1983; Chen et al., 1990). Results were expressed as c.p.m. in a $1 \mathrm{ml}$ incubation reaction, or as pmol amino acid incorporated per $10^{9} \mathrm{C}$. burnetii organisms.

Alternatively, some samples were resuspended in electrophoresis sample buffer (lacking bromophenyl blue) and were radioassayed in a water-miscible scintillation cocktail prior to application to electrophoresis gels.

PAGE of proteins. Four different sample types were subjected to SDS-PAGE. (1) The cell supernatants containing radiolabelled polypeptides were concentrated by use of Minicon CS15 macrosolute concentrators (Amicon, $15 \mathrm{kDa}$ molecular mass cutoff). Wells of concentrators were first rinsed with a $1 \mathrm{mg} \mathrm{ml} \mathbf{m}^{-1}$ solution of bovine serum albumin. Supernatant solutions $(0.6 \mathrm{ml}$ volumes) were added and concentrated to a final volume of approximately $50 \mu \mathrm{l}$. Each concentrated sample was added to an equal volume of electrophoresis sample buffer $(0.16 \mathrm{M}$ Tris/HCl, pH 6.8, 3.2\% SDS, 32.3\% glycerol, $0.45 \mathrm{M} \mathrm{2-}$ mercaptoethanol, and 1-2 drops of $0.01 \%$ bromophenyl blue) and boiled for $5 \mathrm{~min}$. (2) Cell pellets were extracted for protein by a freeze-lysis method. They were suspended in $10 \mathrm{mM}$ Tris/ $\mathrm{HCl}, \mathrm{pH} 7 \cdot 4$, containing $1 \mathrm{mM} \mathrm{MgCl}_{2}, 1 \mathrm{mg}$ egg white lysozyme $\mathrm{ml}^{-1}$ and $12 \mu \mathrm{g} \mathrm{DNase} \mathrm{ml}^{-1}$. Organisms were then lysed by five cycles of freeze-thawing in a dry ice/acetone bath and a $37^{\circ} \mathrm{C}$ water bath, respectively. Nonidet P-40 was added to a final concentration of $0.6 \%$, followed by incubation for $1 \mathrm{~h}$ at room temperature. Extracted protein was added to an equal volume of electrophoresis sample buffer and boiled for $5 \mathrm{~min}$ prior to electrophoresis. (3) The membrane ( $\mathrm{NaOH}$-insoluble) and (4) cytoplasmic fractions prepared as described (above) were washed once in Hanks' balanced salts solution and protein 
pellets were resuspended directly in electrophoresis sample buffer and boiled for $5 \mathrm{~min}$.

After cooling, boiled samples $(40 \mu \mathrm{l})$ were electrophoresed in $6-15 \%$ linear gradient polyacrylamide slab gels at $150 \mathrm{~V}$ and $15{ }^{\circ} \mathrm{C}$. After staining and destaining to locate standard markers, gels were fixed in $50 \%$ methanol $/ 30 \%$ acetic acid for $10 \mathrm{~min}$, impregnated with $\mathrm{En}^{3} \mathrm{Hance}$ (New England Nuclear) for $1 \mathrm{~h}$ and then washed in $3 \%(\mathrm{v} / \mathrm{v})$ glycerol for $1 \mathrm{~h}$. Gels were dried under vacuum and exposed to Kodak Royal X-Omat AR film at $-70{ }^{\circ} \mathrm{C}$ for the times indicated.

Sources of materials. Radioisotopes were purchased from Amersham. Dulbecco's Modified Eagle's medium and newborn calf serum were obtained from GIBCO. $N, N^{\prime}$-Dicyclohexylcarbodiimide (DCCD), bovine serum albumin (fraction V, no. A7906), egg white lysozyme and DNase were purchased from Sigma. Carbonyl cyanide $m$-chlorophenylhydrazone (CCCP) was from Calbiochem. All electrophoresis reagents were obtained from Bio-Rad. En ${ }^{3}$ Hance and other liquid scintillation reagents were purchased from New England Nuclear.

\section{RESULTS}

\section{Characterization of the protein translocation process}

When either naturally or mechanically released $C$. burnetii cells are incubated with oxidizable substrate and radiolabelled amino acid in buffered salts solution at $\mathrm{pH} 4 \cdot 5$, a significant amount of amino acid is incorporated into protein throughout a $16 \mathrm{~h}$ incubation period (Zuerner \& Thompson, 1983; Thompson et al., 1984, 1990; Chen et al., 1990). In the present work, the distribution of this de novo-synthesized protein was determined. Secretion, release or leakage of protein synthesized de novo during acid activation by naturally released organisms was a consistent observation. Over a period of $16 \mathrm{~h}$ of activation in the presence of radiolabelled amino acid, naturally released organisms incorporated a total of between 800 and $1494 \mathrm{pmol}$ leucine (per $10^{9}$ organisms) into total protein (sum of structural plus secreted) in five different experimental trials (results not shown; the five trials comprised organisms harvested from five different batches of IBHK cells of various passage histories on five different dates over a period of six months). In those same trials, mechanically released $C$. burnetii were not as active, incorporating $118-390 \mathrm{pmol}$ per $10^{9}$ organisms. The secretion process was observed regardless of the concentrations of organisms activated and the amino acid label used $\left(\left[{ }^{35} \mathrm{~S}\right]\right.$ methionine, $\left[{ }^{3} \mathrm{H}\right]-$ or $\left[{ }^{14} \mathrm{C}\right]$ leucine, or $\left[{ }^{3} \mathrm{H}\right]$ proline are all effective in tracing secreted protein); the patterns of peptide and polypeptide species detected after electrophoresis and fluorography differed somewhat in minor details depending upon which of these precursors was used (not shown), and the quantity of protein synthesized and secreted varied proportionately with the concentration of organisms being activated (not shown). The mechanically released organisms consistently secreted little if any de novo-synthesized protein. In contrast, after $16 \mathrm{~h}$ of acid activation the naturally released organisms had secreted $13-54 \%$ (five trials) of the total de novosynthesized protein.

Typical compartmentalization of incorporated leucine after this period of synthesis, in both naturally and mechanically released cells, is shown in Table 1. Approximately $28 \%$ of the total TCA-precipitable radioactivity recovered had accumulated in the medium during incubation of naturally released $C$. burnetii. In contrast, mechanically released C. burnetii distributed only $2 \cdot 4 \%$ of the labelled protein into the medium. When activation studies were carried out with $\left[{ }^{3} \mathrm{H}\right]$ proline, very similar distributions were found: naturally released organisms secreted $26.9 \%$ and mechanically released, $6.0 \%$ (not shown). Both cell populations compartmentalized a large amount of the de novo-synthesized protein into a membranous, alkali-insoluble fraction (Table 1). Both retained a significant amount (usually $40-50 \%$ of the total incorporated counts) in the alkali-soluble cytoplasmic fraction.

Table 1. Distribution of proteins labelled with $\mathrm{L}-\left[{ }^{3} \mathrm{H}\right]$ leucine during acid activation of $\mathrm{C}$. burnetii cells

\begin{tabular}{|c|c|c|c|c|c|c|c|c|c|}
\hline \multirow[t]{3}{*}{ Cell type } & \multicolumn{2}{|c|}{ Total incorporation* } & \multirow{2}{*}{\multicolumn{2}{|c|}{$\begin{array}{l}\text { Incorporated into } \\
\text { proteins secreted } \\
\text { into medium } \ddagger\end{array}$}} & \multicolumn{4}{|c|}{ Incorporated into cell-associated proteins $₫$} & \multirow{3}{*}{$\begin{array}{c}\text { Recovery } \\
\text { ( } \% \text { of } \\
\text { total) }\end{array}$} \\
\hline & \multirow[t]{2}{*}{$10^{-3} \times$ C.p.m. $\dagger$} & \multirow{2}{*}{$\begin{array}{l}\% \text { of } \\
\text { total }\end{array}$} & & & \multicolumn{2}{|c|}{$\mathrm{NaOH}$-insoluble } & \multicolumn{2}{|c|}{$\mathrm{NaOH}$ soluble } & \\
\hline & & & $10^{-3} \times$ C.p.m. & $\begin{array}{l}\% \text { of } \\
\text { total }\end{array}$ & $10^{-3} \times$ C.p.m. & $\begin{array}{l}\% \text { of } \\
\text { total }\end{array}$ & $10^{-3} \times$ C.p.m. & $\begin{array}{l}\% \text { of } \\
\text { total }\end{array}$ & \\
\hline $\begin{array}{l}\text { Naturally } \\
\text { released }\end{array}$ & 2054 & 100 & 569 & $27 \cdot 7$ & 366 & $17 \cdot 8$ & 837 & $40 \cdot 7$ & $86 \cdot 2$ \\
\hline $\begin{array}{l}\text { Mechanically } \\
\text { released }\end{array}$ & 782 & 100 & 19 & $2 \cdot 4$ & 205 & $26 \cdot 2$ & 337 & $43 \cdot 1$ & $71 \cdot 7$ \\
\hline
\end{tabular}

* Total incorporation represents hot TCA-precipitable radioactivity measured at the end of the $16 \mathrm{~h}$ incubation, prior to separation of cells from the reaction medium.

† Uncorrected counts are shown. One picomole of leucine is equivalent to 545 c.p.m. Counting efficiency was $25 \%$ and did not vary significantly from sample to sample.

$\ddagger$ Hot TCA-precipitable counts found in the supernatant fraction after centrifugation of reaction medium.

\elleted cells were fractionated as described by Russel \& Model (1982). By this method, the alkali-insoluble fraction contains membrane (inner plus outer) proteins and the soluble fraction presumably contains cytoplasmic and periplasmic proteins. 


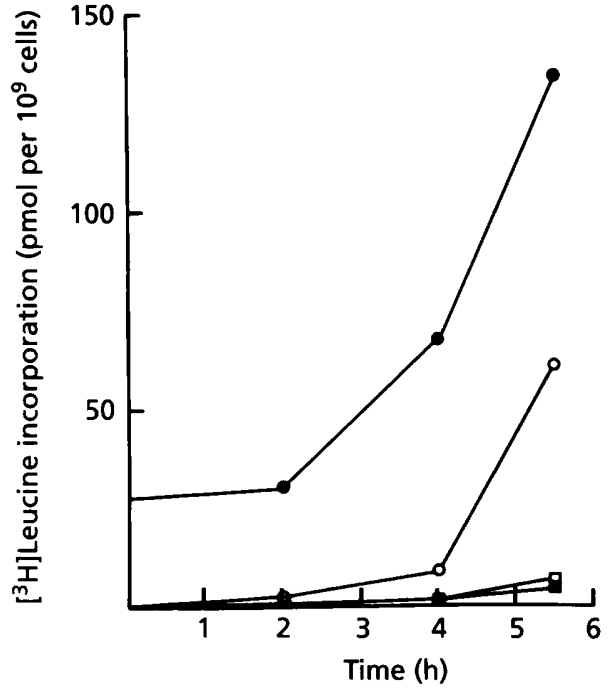

Fig. 1. Long-term time study of the secretion of radiolabelled protein into the medium by naturally-released $C$. burnetii during acid activation. Proteins were labelled with L$\left[{ }^{3} \mathrm{H}\right]$ leucine, and supernatant protein radioactivity determined as described in Methods. In experiment 2 (filled symbols), phenylmethylsulfonyl fluoride (PMSF; $2 \mathrm{mM}$ ) was added to aliquots after they were removed (from acid activation mixtures) and chilled, to reduce protease activity prior to radioassay. The presence of $2.0 \mathrm{mM}$ PMSF during activation severely inhibited leucine incorporation. 0,0 . Acid activation at $\mathrm{pH} 4.5 ; \square, \square$, control incubations at $\mathrm{pH} 7.0$.

A time-course of protein translocation to the medium during acid activation of naturally released organisms was established (Fig. 1). Except in experiments designed specifically to study the kinetics and energetics of secretion (see below), the extracellular accumulation of protein was usually detectable only after $2 \mathrm{~h}$ or more of incubation. The rate of protein accumulation in the medium thereafter increased, especially between 2 and $4 \mathrm{~h}$ of incubation. From these results, which were also reasonably consistent, it was suspected that protein secretion competence in these organisms developed only after $2 \mathrm{~h}$ or more of metabolic activation (acid activation) within the defined medium.

The fate of protein synthesized (and radiolabelled in situ) by $C$. burnetii during a normal growth cycle in tissue culture fibroblasts was also investigated. IBHK cells in monolayer culture were labelled for $12 \mathrm{~h}$ with $\left[{ }^{3} \mathrm{H}\right]$ leucine in the presence of cycloheximide (to reduce host-cell protein synthesis). Radiolabelled, naturally released $C$. burnetii cells were allowed to accumulate in the medium, were harvested by the usual protocol, and were then acidactivated under precisely the same conditions as described above, except that these activations contained no radiolabelled amino acids. The experiment also included measurement of prelabelled protein lost from mechanically released $C$. burnetii; the latter served as a negative control. For both cell types (naturally and mechanically released), only small quantities $(2.1 \%$ and $4.0 \%$, respectively) of prelabelled cellular protein were recovered
Table 2. Effect of inhibitors on the distribution of $\mathrm{L}-\left[{ }^{14} \mathrm{C}\right]$ leucine into TCA-precipitable radioactivity

\begin{tabular}{|lcc|}
\hline Conditions used & \multicolumn{2}{c|}{$\left[{ }^{14} \mathbf{C}\right]$ Leucine incorporated* } \\
\cline { 2 - 3 } & Cell-associated & In medium \\
\hline Complete system & & \\
pH 7.0 & 2.08 & $9 \cdot 3$ \\
pH 4.5 & 41.81 & 29.6 \\
Amino acids omitted $\dagger$ & 2.5 & $9 \cdot 3$ \\
Glucose omitted & 26.9 & 18.1 \\
High glucose (2 mM) & 105.5 & 39.4 \\
Plus chloramphenicol & 4.2 & 10.7 \\
Plus DCCD & 5.56 & $8 \cdot 1$ \\
Plus CCCP & 1.67 & 6.6 \\
\hline
\end{tabular}

* Values are expressed as pmol $\left[{ }^{14} \mathrm{C}\right]$ leucine incorporated per $10^{9}$ cells, during a $7 \mathrm{~h}$ acid-activation incubation using standard conditions (see text).

†Only radiolabelled leucine was added; no other amino acids were included, labelled or otherwise.

from the medium following a $4 \mathrm{~h}$ incubation. The results were similar when non-radiolabelled protein synthesis was inhibited using chloramphenicol during the $4 \mathrm{~h}$ incubation (not shown). These results indicate that cellular integrity was maintained during the harvesting and incubation procedures and that large amounts of prelabelled protein were not lost from either $C$. burnetii cell type.

\section{Effect of metabolic inhibitors on protein accumulation}

The data presented thus far are consistent with a physiological protein secretion mechanism in naturally released C. burnetii. But it was possible that an extracellular or cell-surface-located reaction converted ${ }^{3} \mathrm{H}$ in $\left[{ }^{3} \mathrm{H}\right]$ leucine or $\left[{ }^{3} \mathrm{H}\right]$ proline from a TCA-soluble to TCAprecipitable form, or that some other conversion, such as the extremely tight chelation of radiolabelled amino acid by a periplasmic binding protein, might explain some of these results. To test this possibility, the effect of inhibitors, amino acids and glucose upon the distribution of $\mathrm{L}-\left[\mathrm{U}-{ }^{14} \mathrm{C}\right]$ leucine into insoluble fractions was investigated. Naturally released $C$. burnetii were incubated in defined medium for $7 \mathrm{~h}$ under the various conditions shown (Table 2), and cell pellets recovered. All variables tested had profound effects upon the amount of TCAinsoluble radioactivity that was recovered in both the medium and the cell pellet (Table 2), but in all cases the quantities of radioactive protein found in $C$. burnetii supernates changed in parallel with those found in the pellet (cellular) fractions. Thus, appearance of $\left[{ }^{14} \mathrm{C}\right]$ leucine in the extracellular, TCA-precipitable fraction was dependent upon cytoplasmic protein synthesis (it was inhibited by chloramphenicol) and energy metabolism (it 
A

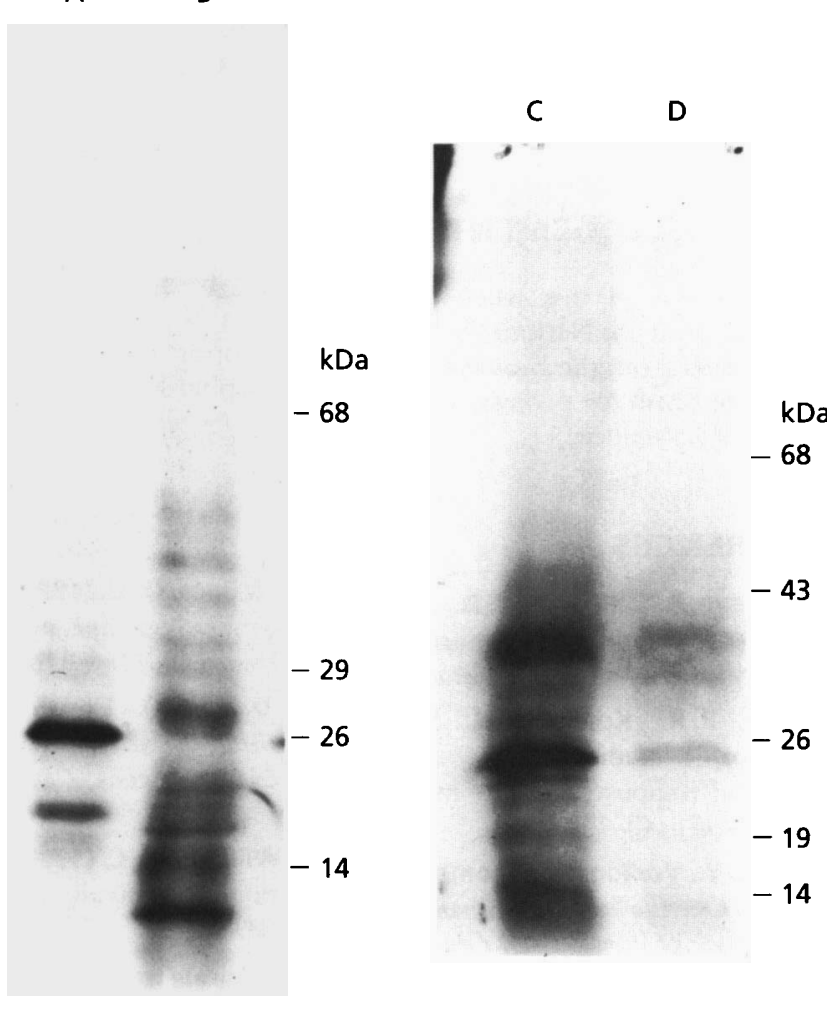

Fig. 2. PAGE analysis of de novo-synthesized proteins found in extracellular, membrane and cytoplasmic compartments after acid activation of naturally-released $\mathrm{C}$. burnetii. Lane $\mathrm{A}, \mathrm{NaOH}-$ insoluble (membrane) proteins; lane $\mathrm{B}, \mathrm{NaOH}$-soluble (periplasmic and cytoplasmic) proteins; lane $C$, supernatant proteins secreted by naturally released $C$. burnetii; lane $D$, supernatant proteins secreted by mechanically released $C$. burnetii.

was inhibited by the membrane ATPase inhibitor DCCD and by the proton ionophore CCCP), and also required the presence of metabolic substrates (amino acids including glutamate, plus glucose). The data, obtained from an experiment where $\left[{ }^{14} \mathrm{C}\right]$ leucine rather than $\left[{ }^{3} \mathrm{H}\right]$ leucine was used, thus argue against an extracellular process being responsible for the ${ }^{3} \mathrm{H}$ incorporation observed in other experiments. Rather, de novo protein synthesis was required prior to the appearance of TCA-precipitable radioactivity in the medium.

\section{Characterization of translocated proteins}

Proteins which had accumulated in the medium during a $16 \mathrm{~h}$ period of acid activation were concentrated and examined by SDS-PAGE and fluorography. Only a few major labelled bands, corresponding to molecular masses of 34, 24 and $12 \mathrm{kDa}$, were detected (Fig. 2, lane C). The presence of low-molecular-mass bands cannot be precisely explained. The procedure used to concentrate supernatant samples should have excluded fragments smaller than $15 \mathrm{kDa}$. These smaller fragments may represent residual quantities of a protein initially present in much larger amounts or, alternatively, components of a larger protein that dissociates during sample preparation for electrophoresis. The mechanically released organisms secreted much less protein (see also Fig. 1), but produced a qualitatively similar pattern of proteins (Fig. 2, lane D), except that proportionally less of the components of lowest molecular mass were evident.

In order to determine if there were correlations in molecular mass between secreted proteins and those found in either membrane or cytoplasmic fractions, cellular pellets were extracted by the $\mathrm{NaOH}$ fractionation method. Alkali-insoluble and soluble fractions were boiled in SDS/2-mercaptoethanol, electrophoresed, and fluorographed. The membrane fraction (alkali-insoluble, Fig. 2, lane A) contained two major labelled species of approximately 26 and $20 \mathrm{kDa}$; several minor labelled bands, ranging from about 90 to $10 \mathrm{kDa}$, were also evident. Cytoplasmic fraction proteins are shown in Fig. 2, lane B. It is clear that the heavily labelled, $26 \mathrm{kDa}$ protein associated with the membrane (lane A) has no obvious size counterpart in the cytoplasm (lane B). Overall, there was little size correlation between labelled species found in the cytoplasmic fraction when compared with the membrane fractions. Further, except for the $24 \mathrm{kDa}$ protein, there was little size similarity between extracellular, secreted proteins and those found in the cytoplasmic compartment.

\section{DISCUSSION}

It was originally hypothesized that protein release by $C$. burnetii represented nonspecific leakage. The present experiments were designed to test this hypothesis, according to which it would be predicted that (i) energy poisons or proton ionophores should not affect protein release; (ii) proteins labelled in situ during tissue culture growth should be released during subsequent acidactivation incubation; (iii) electrophoresis patterns of released proteins should shadow or resemble those of the cytoplasmic proteins; (iv) the leakage of radiolabelled protein to the exterior should be detectable as soon as cytoplasmic protein becomes radiolabelled by de novo synthesis. The data that have been obtained do not accord with the hypothesis. Instead, they indicate specific secretion of selected proteins synthesized de novo during acid activation. Mechanically released cells secrete almost no protein. Development of competence for secretion in naturally released cells appears to be time dependent, occurring only after $2-4 \mathrm{~h}$ of acid activation. Activation by low $\mathrm{pH}$ does not appear to damage organisms, since prelabelled protein does not leak from cells. Also, the secreted protein pattern on gels does not mirror that of the cytoplasmic proteins, eliminating a general leakage phenomenon.

The naturally released population of $C$. burnetii has been previously examined by electron microscopy (McCaul et al., 1991a; Redd, 1986). Evidence for damaged organisms was not found in those studies; however, naturally released organisms in various stages of differentiation, 
from large to small cell variants, were obvious. A connection between a differentiation stage and protein secretion therefore cannot be ruled out.

It was previously reported that the $58 \mathrm{kDa} h t p B$ gene product, which is a heat-shock protein in $C$. burnetii and is analogous to the E. coli groEL protein, dissociates from naturally released $C$. burnetii following induction of its synthesis in vitro (Thompson et al., 1990). Those studies also showed that a predominant, non-heat-shock protein of approximately $28 \mathrm{kDa}$ is synthesized and secreted during incubations of naturally released $C$. burnetii at $21^{\circ} \mathrm{C}$ and, to a lesser extent, at $42^{\circ} \mathrm{C}$. Thus the data in this report, as well as those reported previously from this laboratory, are consistent in the observation that naturally released $C$. burnetii organisms are protein secretors (Thompson $e$ tal., 1984, 1990). A specific and small subset of proteins, rather than a random group, seems to participate in this translocation. Most notably, the synthesis, translocation and secretion of a protein (or a set of polypeptides) variously estimated on gels to be $24-29 \mathrm{kDa}$ in size has been consistently observed during acid activation of $C$. burnetii organisms harvested from tissue culture media. It has been suggested that the protein may be the com 1 gene product, which is an outer-membrane protein in C. burnetii (Hendrix et al., 1993). com 1 has a motif that resembles the active site of a protein disulfide oxidoreductase (Hendrix et al., 1993). Alternatively, the discovery of a similar-sized C. burnetii surface protein, termed simply the $29.5 \mathrm{kDa}$ protein, may instead be related to the present observations; the $29 \cdot 5 \mathrm{kDa}$ protein is probably not com1 (McCaul et al., 1991b).

Organisms obtained by intentional shear lysis (mechanically released) of infected host fibroblasts do not secrete significant amounts of protein. If this is indicative of the culture stage from which they were obtained, i.e. phagolysosome-bound organisms, and if gene expression and cellular processses observed during acid activation are an accurate reflection of the stage from which the organisms were previously obtained, then a possible conclusion is that the intracellular organisms in these long-term persistent infections are not protein secretors. Thus phagocytosed C. burnetii might secrete stage-specific proteins primarily after the initial $\mathrm{pH}$ shock of phagosome-lysosome fusion and only after traversing an extracellular stage. Organisms may not secrete, or may do so less actively, during later stages of growth and development within the phagolysosome. Alternatively, it is possible that the protein secreted represents a subset of gene products not made in vivo, but unique to acid activation in vitro.

Invasive bacteria might be expected to express and secrete proteins primarily as a consequence of their interactions with hosts. Some of these proteins may modify host function (Thompson, 1988; Small et al., 1994). Furthermore, Coxiella might synthesize and secrete proteins specific for its infectious cycle or developmental cycle (McCaul et al., 1991a). How these potential protein functions relate to the present observations remains uncertain. However, a means by which to study and obtain secreted protein has been established, and this may benefit studies of pathogenic functions and of host interaction.

\section{ACKNOWLEDGEMENTS}

Initial phases of this work were supported by grant PCM7903282 from the National Science Foundation. We are grateful for support from the Biomedical Research Support Committee, WVU, to finish the project. We thank Christopher Kolanko for technical assistance.

\section{REFERENCES}

Akporiaye, E. T., Rowatt, J. D., Aragon, A. A. \& Baca, O. G. (1983). Lysosomal response of a murine macrophage-like cell line persistently infected with Coxiella burnetii. Infect Immun 40, 1155-1162.

Burton, P. R., Kordova, N. \& Paretsky, D. (1971). Electron microscopic studies of the rickettsia Coxiella burnetii: entry, lysosomal response, and fate of rickettsial DNA in L-cells. Can J Microbiol 17, 143-150.

Chen, S.-Y., Vodkin, M., Thompson, H. A. \& Williams, J. C. (1990). Isolated Coxiella burnetii synthesizes DNA during acid activation in the absence of host cells. J Gen Microbiol 136, 89-96.

Hackstadt, T. \& Williams, J. C. (1981a). Biochemical stratagem for obligate parasitism of eukaryotic cells by Coxiella burnetii. Proc Natl Acad Sci US A 78, 3240-3248.

Hackstadt, T. \& Williams, J. C. (1981b). Stability of the adenosine 5 -triphosphate pool in Coxiella burnetii; influence of $\mathrm{pH}$ and substrate. J Bacteriol 154, 419-425.

Hendrix, L. R., Mallavia, L. P. \& Samuel, J. E. (1993). Cloning and sequencing of Coxiella burnetii outer membrane protein gene com 1 . Infect Immun 61, 470-477.

McCaul, T. F., Williams, J. C. \& Thompson, H. A. (1991a). Electron microscopy of Coxiella burnetii in tissue culture. Induction of cell types as products of the developmental cycle. Acta Virol 35, 545-556.

McCaul, T. F., Banerjee-Bhatnagar, N. \& Williams, J. C. (1991b). Antigenic differences between Coxiella burnetii morphological cell types revealed by post-embedding immunoelectron microscopy and immunoblotting. Infect Immun 59, 3243-3253.

Mans, R. J. \& Novelli, G. D. (1960). A convenient, rapid and sensitive method of measuring the incorporation of radioactive amino acids into protein. Biochem Biophys Res Commun 3, 540-543.

Redd, T. A. (1986). Secreted protein of Coxiella burnetii. $\mathrm{PhD}$ dissertation, West Virginia University.

Russel, M. \& Model, P. (1982). Filamentous phage pre-coat is an integral membrane protein: analysis by a new method of membrane preparation. Cell 28, 177-184.

Silverman, D. J., Fiset, P. \& Wisseman, C. L., Jr (1979). Simple, differential staining technique for enumerating rickettsiae in yolk sac, tissue culture, extracts, or purified suspensions. J Clin Microbiol 9, 437-440.

Small, P. L., Ramakrishnan, L. \& Falkow, S. (1994). Remodeling schemes of intracellular pathogens. Science 263, 637-639.

Thompson, H. A. (1988). Relationship of the physiology and composition of Coxiella burnetii to the Coxiella-host cell interaction. In Biology of Rickettsial Diseases, vol. II, p. 78. Edited by D. H. Walker. Boca Raton, FL: CRC Press. 
Thompson, H. A., Zuerner, R. L. \& Redd, T. (1984). Protein synthesis in Coxiella burnetii. In Microbiology 1984, pp. 288-292. Edited by D. Schlessinger. Washington, DC: American Society for Microbiology.

Thompson, H. A., Bolt, C. R., Hoover, T. \& Williams, J. C. (1990). Induction of heat shock proteins in Coxiella burnetii. Ann NY Acad Sci 590, 127-135.

Williams, J. C. (1981). Iodination of Coxiella burnetii cells: optimal conditions for the iodination of exposed surface proteins. In Rickettsiae and Rickettsial Diseases, pp. 473-482. Edited by W. Burgdorfer \& R. L. Anacker. New York: Academic Press.
Williams, J. C. \& Waag, D. M. (1991). Antigens, virulence factors, and biological response modifiers of Coxiella burnetii: strategies for vaccine development. In $Q$ Fever: the Biology of Coxiella burnetii, pp. 175-222. Edited by J. C. Williams \& H. A. Thompson. Boca Raton, FL: CRC Press.

Zuerner, R. L. \& Thompson, H. A. (1983). Protein synthesis by intact Coxiella burnetii cells. J Bacteriol 156, 186-191.

Received 9 June 1994; revised 15 September 1994; accepted 24 October 1994. 